\title{
Symulacja i predykcja erozji wybrzeża wybranych odcinków Zatoki Gdańskiej w modelu SWAN
}

\author{
Patryk Sapiega ${ }^{1}$
}

\begin{abstract}
Simulation and forecast of coastal erosion in the Gulf of Gdańsk in the SWAN model. Prz. Geol., 69: 721-727; doi: 10.7306/2021.40
A b s t r a c t. The increasing climatic changes and their possible negative impact on the marine and coastal environment prompt the search for alternative estimating and predicting dangerous phenomena. Hydrodynamic modeling is an underappreciated model which enables forecasting waves and their effects. In the presented work, the author assessed the influence of the dynamics of undulations on the morphological changes of the Gulf of Gdańsk coast in three transects representing different geomorphological zones of the shore. Using the SWAN wave model, simulations were carried out reflecting the hydrodynamic conditions of the most giant storms in 2015-2020, calculating the amount of eroded sediment material in bottom and suspension transport. In addition, based on the significant wave height data from ERA5-ECMWF from 1981-2020 and the assumed scenarios, a prediction was made of a potential increase in coastal erosion caused by the rise in the mean value of the significant wave height. Taking into account the implemented and set atmospheric, hydrodynamic, and sedimentological conditions, it has been estimated that the highest erosion characterizes the cliff area in Gdynia-Ortowo (transect B), where the average amount of erosion of the bottom sediment is $0.5 \mathrm{~kg} / \mathrm{m} / \mathrm{s}$, of the sediment in suspension $-20 \mathrm{~kg} / \mathrm{m} / \mathrm{s}$, and the average speed of the transported sediment exceeds $2 \mathrm{~m} \cdot \mathrm{s}^{-1}$. The lowest dynamics of changes is characteristic for the western part of the Vistula Spit (transect C), where the average velocity of the transported sediment is $0.28 \mathrm{~m} \cdot \mathrm{s}^{-1}$, and the average size of the eroded bottom sediment is $0.014 \mathrm{~kg} / \mathrm{m} / \mathrm{s}$ and $0.15 \mathrm{~kg}$ in suspension $/ \mathrm{m} / \mathrm{s}$. In the analyzed storm events, at all locations, the greatest erosion was generated by the wave conditions from January 2019. The maximum wave height in the open sea was record-breaking, over 13 meters. Depending on the analyzed area and its geomorphology and exposure to storm waves, the predicted amount of erosion varied significantly. For Scenario A, assuming a 15\% increase in the average frequency and height of the significant wave, the forecast of coastal transport is 138-161 thousand $\mathrm{m}^{3} /$ year, for Scenario B (30\%) 150-175.5 thousand $\mathrm{m}^{3} /$ year, and for Scenario $C(50 \%)$ 180-210 thousand $\mathrm{m}^{3} / y e a r$. In addition, the aim of the work is a cause-and-effect analysis of wave activity on the coast of the Gulf of Gdan'sk and the assessment of its impact on quantitative changes in the sediment transport balance.
\end{abstract}

Keywords: erosion, Gulf of Gdansk, numerical model SWAN

Prognozowanie i analizowanie zmian tempa erozji wybrzeża jest ważne zarówno z punktu widzenia bezpieczeństwa ludności miejscowości nadmorskich, jak i ochrony infrastruktury hydrotechnicznej oraz planowania działań z zakresu refulacji plaż czy innych inwestycji prowadzonych w strefie brzegowej. Nasilające się zmiany klimatyczne prowadzą do wzrostu częstości występowania zjawisk sztormowych, które warunkują silną erozję wybrzeża. Stany morza bezpośrednio wpływają na procesy erozyjno-akumulacyjne wybrzeża. Dynamika zmian linii brzegowej południowego Bałtyku pokazuje proces tzw. cofania się plaż oraz erozji wydm i klifów wzdłuż całego polskiego brzegu morskiego. Erozja polskiego wybrzeża była szeroko badana na podstawie pomiarów i symulacji numerycznych (Tubielewicz i in., 1961; Dobracki, Uścinowicz, 2007; Kapiński i in., 2007; Pruszak i in., 2008; Szmytkiewicz i in., 2016, 2017), zaś analiza prezentowana w pracy przedstawia zaktualizowany stan erozji w różnych lokalizacjach Zatoki Gdańskiej w aspekcie oddziaływania największych sztormów z okresu 2015-2020 oraz w ujęciu średniej wartości z 1981-2020. Dynamika zmian jest uzależniona zarówno od czynników antropogenicznych, jak i naturalnych. Na polskim wybrzeżu proces erozji przeważa nad akumulacją. Około 60-70\% polskiego wybrzeża bałtyckiego podlega erozji, której towarzyszy cofanie się linii brzegowej, a także abrazja klifów i wydm. Brzeg morski cofa się średnio o $0,5-0,9 \mathrm{~m}$ rocznie, co prowadzi do utraty 340 tys. $\mathrm{m}^{2}$ lądu na rok (Pruszak, Ostrowski, 2005). Średnia erozja dla polskiego wybrzeża w latach 1875-1979 wynosiła $0,08 \mathrm{~m} / \mathrm{rok}$, w okresie $1960-1983-0,5 \mathrm{~m} / \mathrm{rok}$, a w latach 1971-1983 było to 0,9 m/rok. (Zawadzka-Kahlau, 1999). Widoczne nasilające się tempo erozji wybrzeża w skali 100-lecia objęło 61\% długości brzegu, a w 20-leciu wzrosło do $72 \%$ długości wybrzeża. Znaczącej erozji podlegają odcinki przyległe od wschodu do portów otwartego morza, brzegi Zatoki Gdańskiej od ujścia Martwej Wisły do Mechelinek oraz brzegi morskie Półwyspu Helskiego (Boniecka, 2013).

\section{METODYKA I OBSZAR BADAŃ}

Fale morskie oddziałują na wszystkie strefy wybrzeża, tj. przybrzeże, brzeg i nadbrzeże (ryc. 1). W strefie otwartego morza następuje wzrost wysokości fali, a następnie w wyniku tarcia o dno i rewy fala się łamie i zmniejsza swoją wysokość. W strefie przyboju następuje transformacja fali, zmieniając kierunek propagacji fali. Strefa zmywu i nadbrzeża charakteryzuje się największą podatnością na wymywanie materiału osadowego.

Obszarem badań jest wybrzeże Zatoki Gdańskiej położonej we wschodniej części wybrzeża Polski. W analizie poddano trzy profile (transekty) (ryc. 2), charakteryzujące różną geomorfologię dna i brzegu oraz odmienną ekspozycję na oddziaływanie fal. Każdy z transektów ma długość

\footnotetext{
${ }^{1}$ Instytut Meteorologii i Gospodarki Wodnej - Państwowy Instytut Badawczy, ul. Waszyngtona 42, 81-342 Gdynia; patryk.sapiega@imgw.pl
} 


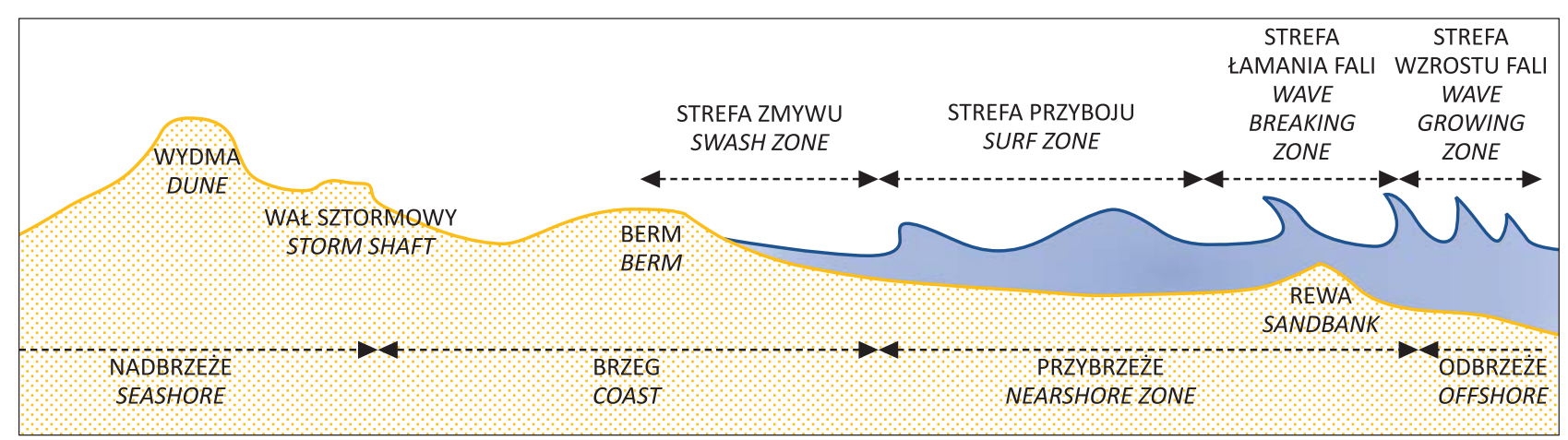

Ryc. 1. Podział strefy brzegowej (na podstawie Gradzińskiego i in., 1986)

Fig. 1. Division of the coastal zone (based on Gradziński et al., 1986)

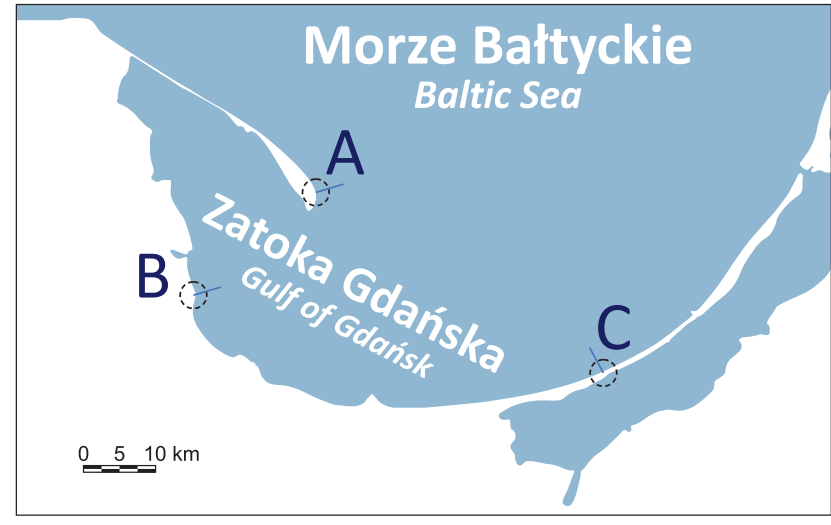

Ryc. 2. Obszar badań wraz z analizowanymi transektami (profilami)

Fig. 2. Study area with analyzed transects

$4 \mathrm{~km}$, a jego punkt początkowy $\mathrm{X}_{\mathrm{p}}(0 \mathrm{~m})$ jest położony przed skłonem wydmy lub klifu.

Głównym narzędziem umożliwiającym symulowanie falowania i jego oddziaływanie na strefę brzegową jest model SWAN (Simulating WAves Nearshore), zasilany i weryfikowany danymi meteorologicznymi i hydrologicznymi pochodzących z modelu COSMO, pomiarów satelitarnych oraz pomiarów rzeczywistych. Do modelu implementowane są takie dane jak: kierunek i prędkość wiatru (rozkład przestrzenny) z krokiem czasowym jednogodzinnym, batymetria dna i hipsometria lądu oraz zadawane warunki początkowe i brzegowe, uwzględniające poziomy morza, prądy morskie, zmienne sedymentologiczne (uziarnienie i porowatość osadu i chropowatość dna) (ryc. 3).

\section{EROZJA BRZEGU WYWOLANA NAJWIECKSZYMI SZTORMAMI W LATACH 2015-2020}

W celu obliczenia transportu erodowanego osadu dennego (Sb) [1], transportu erodowanego osadu w zawiesinie - toni wodnej (Ss) [2] oraz wielkości transportu całkowitej erozji (St) [3] posłużono się formułami autorstwa Leo van Rijna (2013):

$$
\begin{aligned}
& S b=\alpha_{b} \rho_{s} u h\left(\frac{d_{50}}{h}\right)^{1.2} M e^{1.5} \\
& S s=\alpha_{s} \rho_{s} u d_{50} M e^{2.4} d_{*}^{-0.6} \\
& S t=S b+S s
\end{aligned}
$$

Współczynniki $\alpha_{b}$ i $\alpha_{s}$ wynoszą: $\alpha_{b}=0,015$ oraz $\alpha_{s}=0,008-0,012$ i są zalecane przez Van Rijna (2013). Bezwymiarowa wielkość ziarna $\left(d_{*}\right)$ jest opisana wzorem:

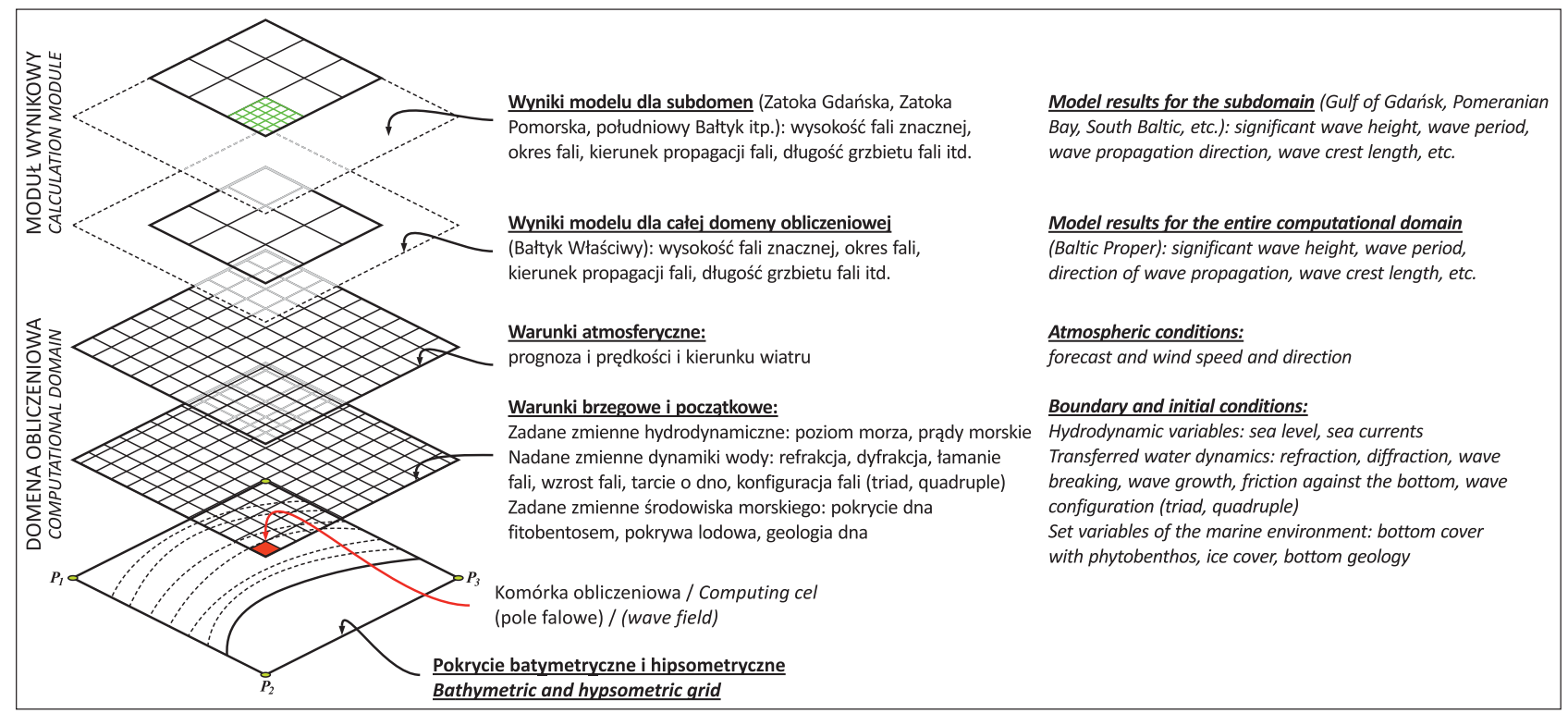

Ryc. 3. Struktura działania i zasilania danymi modelu SWAN

Fig. 3. Structure of operation and data feeding of the SWAN model 


$$
d_{*}=d_{50}\left(\frac{\Delta g}{v^{2}}\right)^{1 / 3}
$$

Mnożnik Me jest obliczany wg wzoru (Visser, 1984):

$$
M e=\max \left[\frac{u_{e}-u_{c}}{\sqrt{\Delta g d_{50}}}, 0\right]
$$

gdzie: $u_{e}=u+\gamma u_{w}$

Składowa naprężenia radiacyjnego $\left(\mathrm{S}_{\mathrm{xy}}\right)$ jest znana w każdym punkcie, gdyż jest obliczana wartość $\mathrm{H}_{\mathrm{s}}$. Uzyskana wartość musi być równa wartości ścinania podłoża (Massie, 1986).

$$
\begin{aligned}
& S_{x y}=\tau_{c w} \\
& \tau_{c w}=\frac{\rho_{w}}{\pi c} \sqrt{2 g f_{w} u \cdot u_{w}}
\end{aligned}
$$

$u$ - jest prędkością przy dnie,

$u_{w}$ - maksymalną prędkością fali:

$$
\begin{gathered}
u=\frac{\frac{d S_{x y}}{d x} \pi c}{u_{w} \rho_{w} \sqrt{2 g f_{w}}} \\
u_{w}=\frac{\pi H_{s}}{T_{p} \sinh \left(\frac{2 \pi}{L} h\right)}
\end{gathered}
$$

$$
\begin{aligned}
& \beta=\frac{u}{u+u_{w}} \\
& u_{c}=\beta u_{c c}+(1-\beta) u_{c w}
\end{aligned}
$$

Współczynnik $\gamma$ wynosi 0,4 dla fal regularnych oraz 0,8 dla fal nieregularnych (Massie, 1986).

$$
u_{c w}=0,24(\Delta g)^{0,66} d_{50}^{0,33} T_{p}^{0,33} \text { dla } 0,0001<d_{50}<0,0005 m
$$

$$
u_{c w}=0,95(\Delta g)^{0,57} d_{50}^{0,43} T_{p}^{0,14} \text { dla } 0,0005<d_{50}<0,002 m
$$

$$
u_{c c}=0,19 d_{50}^{0,1} \log \left(\frac{12 h}{d_{90}}\right) \text { dla } 0,0001<d_{50}<0,0005 m
$$$$
u_{c c}=8,5 d_{50}^{0,6} \log \left(\frac{12 h}{d_{90}}\right) \text { dla } 0,0005<d_{50}<0,002 m
$$

Za wartość $T_{p}$ przyjęto wg Van Rijna (2013): $\mathrm{T}_{\mathrm{p}}=1,1 \mathrm{~T}_{\mathrm{m}-1,0}$, a wartości $\mathrm{T}_{\mathrm{m}}$ pochodzą $\mathrm{z}$ modelu SWAN i zestawiono je w tabeli nr 1 .

Prezentowane w tabeli 2 wartości są zmienne w zależ-

\begin{tabular}{|c|c|c|c|c|c|c|c|c|c|c|c|c|c|c|}
\hline \multirow{3}{*}{\multicolumn{2}{|c|}{$\begin{array}{l}\text { Data sztormu } \\
\text { Storm date }\end{array}$}} & \multirow{2}{*}{\multicolumn{2}{|c|}{$\mathbf{H}_{\mathrm{s}}[\mathbf{m}]$}} & \multirow{2}{*}{\multicolumn{2}{|c|}{$\mathbf{T}_{\mathrm{m}}[\mathbf{s}]$}} & \multirow{4}{*}{$\begin{array}{c}\text { Lokalizacja } \\
\text { Transect }\end{array}$} & \multicolumn{8}{|c|}{ Calkowita erozja / Total erosion $(\mathrm{St})[\mathrm{kg} / \mathrm{m} / \mathrm{s}]$} \\
\hline & & & & & & & \multicolumn{8}{|c|}{ Odległość / Distance $\left(\mathrm{X}_{\mathrm{p}}\right)[\mathrm{m}]$} \\
\hline & & $\mathbf{X}_{\mathrm{p}}$ & $\mathbf{X}_{\mathrm{k}}$ & $\mathbf{X}_{\mathbf{p}}$ & $\mathbf{X}_{\mathrm{s}}$ & & $\mathbf{0}$ & 50 & 100 & 500 & 1000 & 2000 & 3000 & 4000 \\
\hline \multirow{3}{*}{2015} & \multirow{3}{*}{$\begin{array}{l}10.01 .2015 \\
(18: 00)\end{array}$} & 4,59 & 7,3 & 6,28 & 9,4 & & 0,040 & 0,280 & 0,160 & 0,320 & 0,020 & 0,020 & 0,000 & 0,000 \\
\hline & & 2,17 & 3,6 & 2,92 & 4,6 & $\mathrm{~B}$ & 0,150 & 0,924 & 0,600 & 0,200 & 0,010 & 0,010 & 0,000 & 0,000 \\
\hline & & 2,77 & 4,2 & 3,52 & 5,3 & $\mathrm{C}$ & 0,010 & 0,600 & 0,300 & 0,720 & 0,000 & 0,000 & 0,000 & 0,000 \\
\hline \multirow{3}{*}{2016} & \multirow{3}{*}{$\begin{array}{l}26.12 .2016 \\
(15: 00)\end{array}$} & 3,56 & 5,9 & 4,28 & 7,4 & A & 0,020 & 0,240 & 0,140 & 0,300 & 0,020 & 0,010 & 0,000 & 0,000 \\
\hline & & 2,16 & 3,3 & 2,99 & 4,3 & $\mathrm{~B}$ & 0,130 & 0,918 & 0,580 & 0,190 & 0,010 & 0,100 & 0,000 & 0,000 \\
\hline & & 2,32 & 3,6 & 3,14 & 4,4 & $\mathrm{C}$ & 0,010 & 0,530 & 0,240 & 0,660 & 0,000 & 0,000 & 0,000 & 0,000 \\
\hline \multirow{3}{*}{2017} & \multirow{3}{*}{$\begin{array}{l}04.01 .2017 \\
(21: 00)\end{array}$} & 3,98 & 5,6 & 3,80 & 6,3 & A & 0,030 & 0,260 & 0,150 & 0,300 & 0,020 & 0,010 & 0,000 & 0,000 \\
\hline & & 1,74 & 2,9 & 2,40 & 3,6 & $\mathrm{~B}$ & 0,090 & 0,643 & 0,361 & 0,122 & 0,010 & 0,012 & 0,000 & 0,000 \\
\hline & & 2,11 & 3,4 & 3,13 & 4,4 & $\mathrm{C}$ & 0,011 & 0,440 & 0,180 & 0,590 & 0,000 & 0,000 & 0,000 & 0,000 \\
\hline \multirow{3}{*}{2018} & \multirow{3}{*}{$\begin{array}{l}24.10 .2018 \\
(00: 00)\end{array}$} & 3,14 & 4,7 & 3,49 & 5,6 & A & 0,020 & 0,211 & 0,133 & 0,122 & 0,002 & 0,001 & 0,000 & 0,000 \\
\hline & & 2,15 & 3,1 & 2,46 & 3,8 & $\mathrm{~B}$ & 0,129 & 0,915 & 0,580 & 0,190 & 0,010 & 0,100 & 0,000 & 0,000 \\
\hline & & 2,26 & 3,8 & 3,18 & 4,7 & $\mathrm{C}$ & 0,010 & 0,590 & 0,280 & 0,710 & 0,000 & 0,000 & 0,000 & 0,000 \\
\hline \multirow{3}{*}{2019} & \multirow{3}{*}{$\begin{array}{l}02.01 .2019 \\
(03: 00)\end{array}$} & 3,95 & 6,4 & 5,24 & 8,2 & $\mathrm{~A}$ & 0,028 & 0,260 & 0,140 & 0,300 & 0,020 & 0,010 & 0,000 & 0,000 \\
\hline & & 2,01 & 3,2 & 2,43 & 3,5 & B & 0,100 & 0,732 & 0,420 & 0,150 & 0,010 & 0,011 & 0,000 & 0,000 \\
\hline & & 2,72 & 4,8 & 3,18 & 5,6 & $\mathrm{C}$ & 0,010 & 0,600 & 0,300 & 0,520 & 0,000 & 0,000 & 0,000 & 0,000 \\
\hline \multirow{3}{*}{2020} & \multirow{3}{*}{$\begin{array}{l}14.10 .2020 \\
(03: 00)\end{array}$} & 2,93 & 4,8 & 4,09 & 6,1 & $\mathrm{~A}$ & 0,020 & 0,180 & 0,110 & 0,100 & 0,001 & 0,001 & 0,000 & 0,000 \\
\hline & & 1,43 & 2,1 & 1,54 & 2,5 & B & 0,011 & 0,532 & 0,221 & 0,081 & 0,001 & 0,000 & 0,000 & 0,000 \\
\hline & & 2,47 & 3,6 & 2,97 & 4,7 & $\mathrm{C}$ & 0,010 & 0,350 & 0,270 & 0,272 & 0,000 & 0,000 & 0,000 & 0,000 \\
\hline
\end{tabular}
ności od lokalizacji i występującego gruntu dna morskiego. W powyższej tabeli zestawiono przykładowe wartości charakterystyczne dla piasków średnioziarnistych, które wraz z piaskami drobnoziarnistymi stanowiły dominującą frakcję na analizowanych obszarach (Uścinowicz, Zachowicz, 1993; Pikies, Jurowska, 1994).

Tab. 1. Całkowita erozja analizowanych transektów oraz wartości wysokości fali znacznej i średniego okresu fali podczas największych sztormów w latach 2015-2020

Table 1. Total erosion of the analyzed transects and the values of the significant wave height and the mean wave period during the largest storms in 2015-2020 
Dla każdego z profili reprezentujących odmienny obszar: A - Mierzeja Helska, B - Klif Orłowski, C - Mierzeja Wiślana, obliczono wielkość erozji całkowitej (St) wyrażonej $\mathrm{w} \mathrm{kg} / \mathrm{m} / \mathrm{s}$ wg wymodelowanych wartości parametrów falowania i zaimplementowanej batymetrii dna

Tab. 2. Przykładowe wartości zmiennych przyjętych w symulacjach Table 2. Examples of the values of variables adopted in simulations

\begin{tabular}{|l|c|}
\hline \multicolumn{1}{|c|}{$\begin{array}{c}\text { Zmienna } \\
\text { Variable }\end{array}$} & $\begin{array}{c}\text { Przyjęta wartość } \\
\text { Assumed value }\end{array}$ \\
\hline$\rho_{\mathrm{w}}\left[\mathrm{kg} / \mathrm{m}^{3}\right]$ & 1030 \\
\hline$\rho_{\mathrm{o}}\left[\mathrm{kg} / \mathrm{m}^{3}\right]$ & 2650 \\
\hline $\mathrm{d}_{50}[\mathrm{~m}]$ & 0,0003 \\
\hline $\mathrm{d}_{90}[\mathrm{~m}]$ & 0,0005 \\
\hline $\mathrm{n}[-]$ & 0,40 \\
\hline $\mathrm{r}[\mathrm{m}]$ & 0,06 \\
\hline$\gamma$ & $0,4-0,8$ \\
\hline & w zależności od temperatury: \\
lepkość & $0,000001787\left(0^{\circ} \mathrm{C}\right)$ \\
viscosity & $0,000001300\left(10^{\circ} \mathrm{C}\right)$ \\
& $0,000001000\left(20^{\circ} \mathrm{C}\right)$ \\
\hline
\end{tabular}

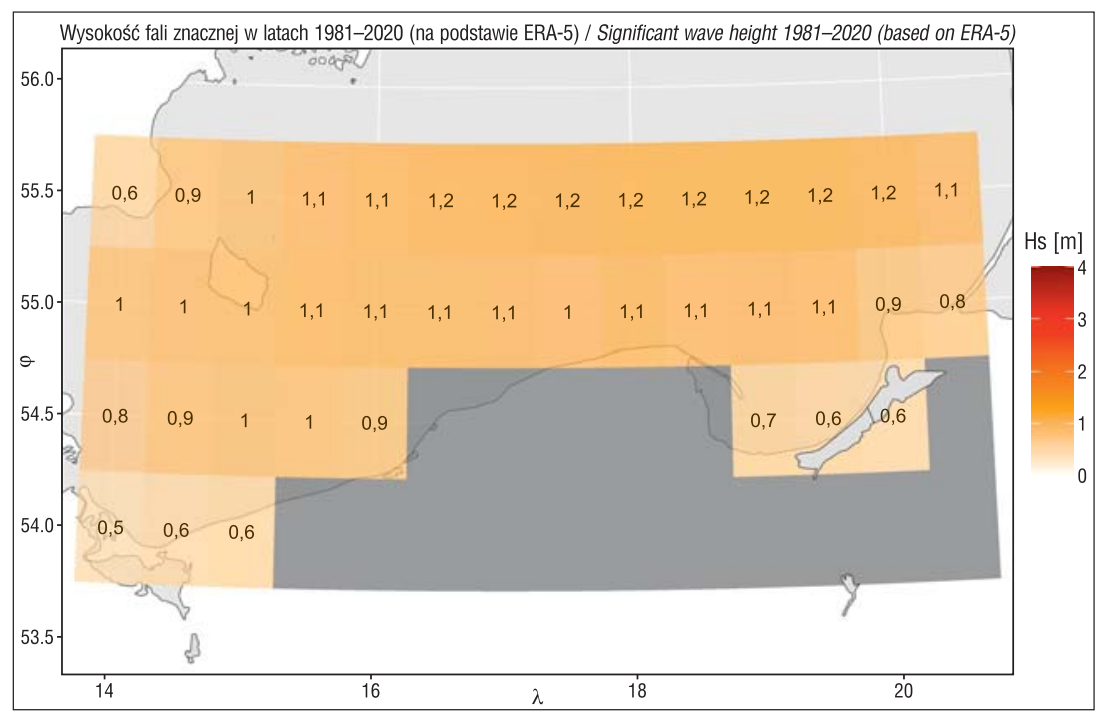

Ryc. 4. Średnia roczna wysokość fali znacznej na obszarze południowego Bałtyku na podstawie ERA5 z okresu 1981-2020 (C3S, 2017)

Fig. 4. Average annual significant wave height in the South Baltic area based on the ERA5 for the 1981-2020 period (C3S, 2017)

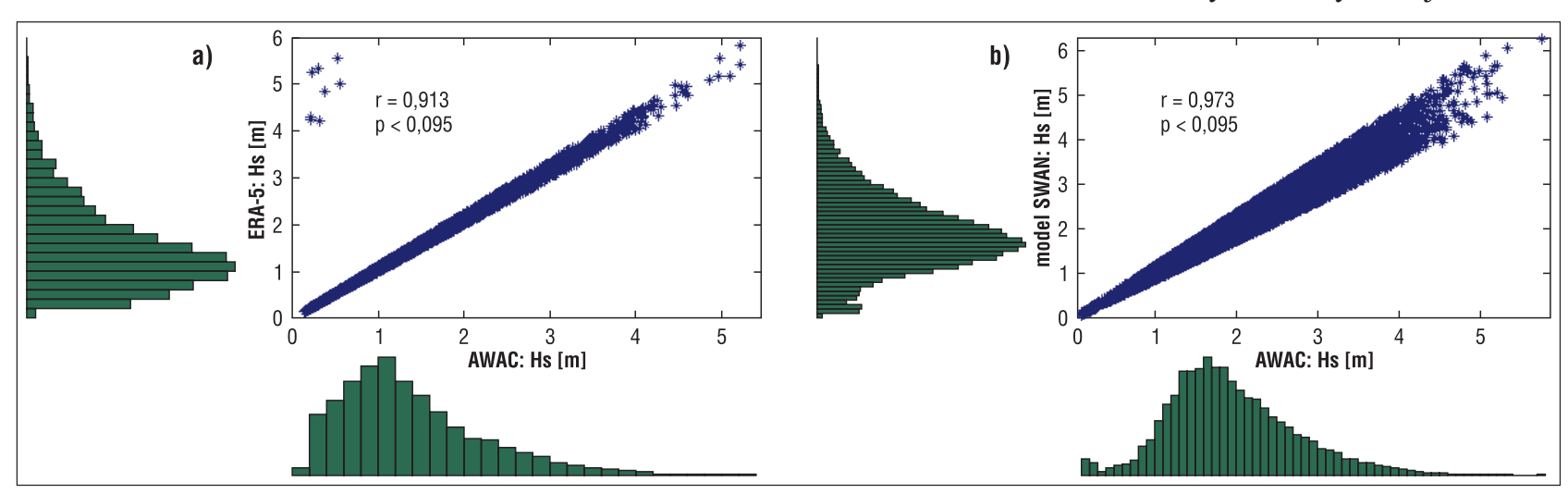

morskiego. W tabeli 1 przedstawiono najniższą wartość $\mathrm{H}_{\mathrm{s}}$ (wysokości fali znacznej) oraz $\mathrm{T}_{\mathrm{m}}$ (średniego okresu fali) na odcinku, zwykle w punkcie początkowym transektu $\left(\mathrm{X}_{\mathrm{p}}\right)$, oraz wartość maksymalną występując a w końcowym punkcie transektu $\left(\mathrm{X}_{\mathrm{k}}\right)$. Najwyższe wartości całkowitej erozji (St) występowały na odcinku $50 \mathrm{~m}$ analizowanych profili we wszystkich analizowanych zdarzeniach sztormowych. Najwyższa erozja była zauważalna w lokalizacji B (Klif Orłowski) i wynosiła ona od 0,532 do 0,924 kg/m/s. Najniższe wartości lub brak erozji obserwowano w odległości powyżej $2 \mathrm{~km}$, a niewielkie wartości występowały na długości 1-2 km. Na odcinku w odległości 500 m, jedynie w lokalizacji C (Mierzeja Wiślana), był zauważalny wzrost erozji, tj. 0,270-720 kg/m/s (tab. 1).

\section{PREDYKCJA I ŚREDNIA EROZJA WYBRZEŻA ANALIZOWANYCH PROFILI}

Znajomość predykcji erodowanego wybrzeża może być kluczowa podczas planowania inwestycji oraz prowadzenia robót w strefie płytkowodnej. Analizowana w pracy średnia wielkość erodowanego wybrzeża może stanowić zgeneralizowany obraz (tło) do bardziej szczegółowych analiz prowadzonych dla mniejszych okresów. W celu określenia zmienności i prognozy wielkości erodowanego brzegu opracowano trzy scenariusze, zakładające potencjalny wzrost warunków hydrodynamicznych, w szczególności wysokości fali znacznej $\left(\mathrm{H}_{\mathrm{s}}\right)$ oraz średniego okres fali $\left(\mathrm{T}_{\mathrm{m}}\right) \mathrm{w}$ stosunku do średniej rocznej obliczonych na podstawie danych z bazy ERA-5 EMCWF (ryc. 4).

Mimo małej rozdzielczości danych $(0,5 \times 0,5$ st. geogr. $)$ pochodzących $\mathrm{z}$ reanalizy, korelacja pomiędzy danymi ERA-5 z okresu 2018-2020 z danymi pomiarowymi wyniosła 0,973 dla korelacji istotnej statystycznie (ryc. 5A). Dane wyjściowe z modelu SWAN, zastosowane w tej analizie, również wskazują na wysoką zgodność odtworzenia rzeczywistych warunków falowych (ryc. 5B).

Zgodnie $\mathrm{z}$ przyjętymi wartościami średnimi parametrów falowania $\mathrm{z}$ okresu 1981-2020 wykonano symulacje wartości

Rys. 5. Zgodność wysokości fali znacznej: A-ERA-5 i danych pomiarowych oraz $\mathbf{B}$ - modelu SWAN i danych pomiarowych w punkcie $\left(55^{\circ} 28^{\prime} 50.85^{\prime \prime} \mathrm{N}, 18^{\circ} 10^{\prime} 56.54 " \mathrm{E}\right)$ dla okresu $2018-2020$

Fig. 5. Significant altitude control: A - ERA-5 and data B - model and control point data ( $55^{\circ} 28^{\prime} 50.85^{\prime \prime} \mathrm{N}$ point, $\left.18^{\circ} 10^{\prime} 56.544^{\prime \prime}\right)$ for the period 2018-2020 


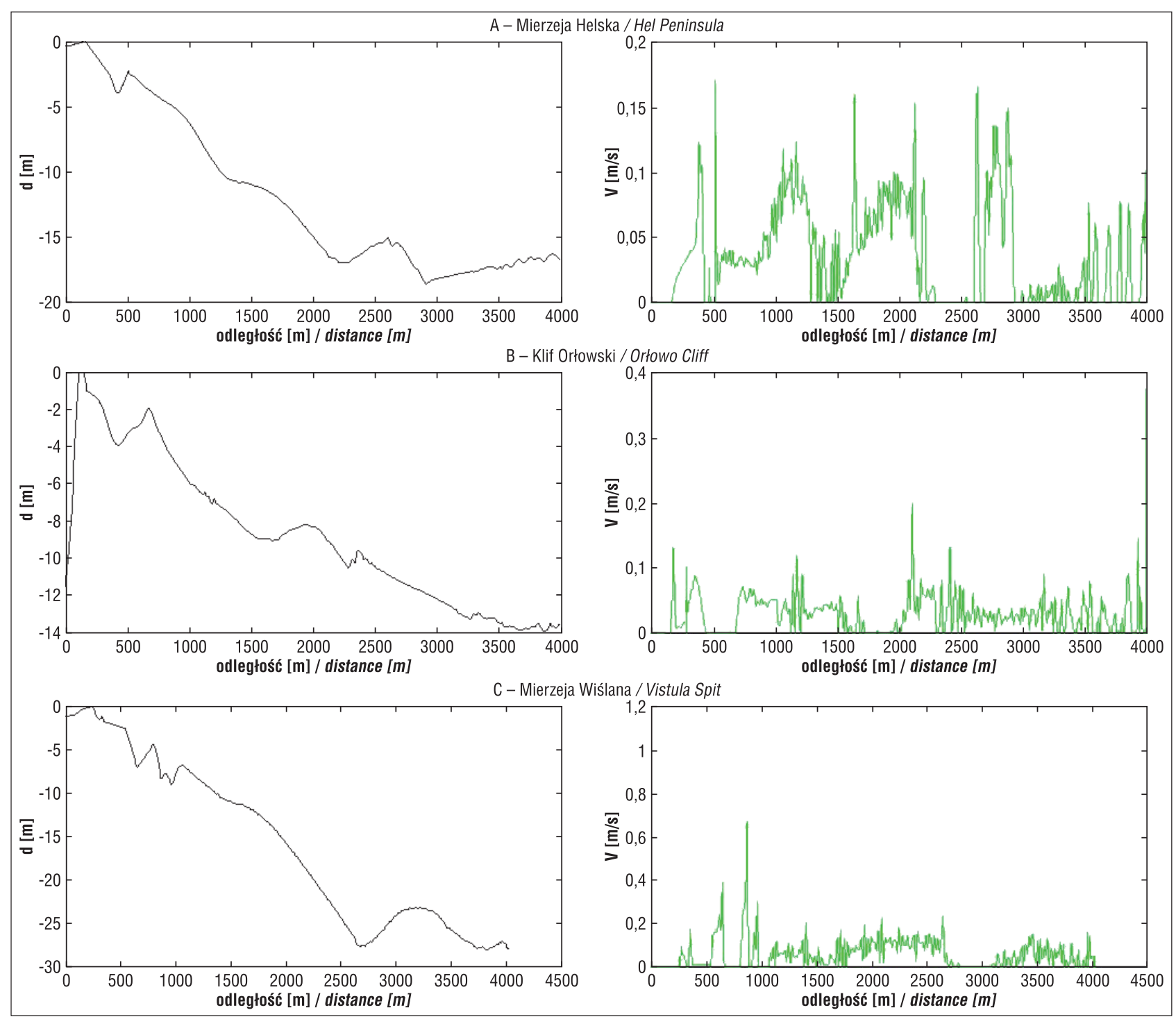

Ryc. 6. Zgeneralizowana prędkość przepływu generowanego na skutek falowania w analizowanych transektach dla średniej z okresu 1981-2020

Fig. 6. Generalized flow velocity generated by undulations in the analyzed transects for the average for the period 1981-2020

prędkości przepływu na skutek falowania w podłożu dna morskiego.

W profilu A (Mierzeja Helska) najwyższe prędkości przepływu występowały na odcinkach 500-1350, 16002150 oraz 2720-2900 m i ich wartość plasowała się w przedziale $0,05-0,1 \mathrm{~m} / \mathrm{s}$. Szczytowe wartości występowały lokalnie w odległości ok. 500, 1650, 2100 oraz 2720 m i przekraczały one $0,15 \mathrm{~m} / \mathrm{s}$.

Zbliżonymi wartościami prędkości przepływu charakteryzował się również profil B (Klif Orłowski), gdzie najwyższa wartość stanowiła $0,2 \mathrm{~m} / \mathrm{s}$. Na większości długości analizowanego transektu wartości te były zbliżone, tj. 0,4-0,8, poza odcinkami $490-618 \mathrm{~m}$ oraz $1740-1890$, gdzie nastapiła stagnacja mas wody i przepływ był znikomy lub zerowy. Na Mierzei Wiślanej (profil C) na przeważającej części transektu wartości nie przekraczały $0,2 \mathrm{~m} / \mathrm{s}$, poza odcinkiem $500-100 \mathrm{~m}(0,2-0,75 \mathrm{~m} / \mathrm{s})$ i ma to związek z występowaniem strefy rewowej na tym odcinku (ryc. 6).

Prędkość przepływu na skutek falowania w podłożu dna morskiego odgrywa kluczową rolę w mechaniźmie generującym erozję wybrzeża. Dla analizowanych profili, implementując dane ERA-5, obliczono erozję osadu dennego (Sb), ilość erodowanego osadu w zawiesinie - toni wodnej (Ss) oraz transport całkowitej erozji (St) (ryc. 7). Dla średnich wartości parametrów falowania $\mathrm{z}$ okresu 1981-2020 największa ilość erodowanego materiału jest widoczna na odcinkach 100-500 m (profil A - Mierzeja Helska i B - Klif Orłowski), a w przypadku profilu C (Mierzeja Wiślana) na odcinku 250-900 m. Maksymalna wartość całkowitej erozji (Ss) wynosiła $0,15 \mathrm{~kg} / \mathrm{m} / \mathrm{s}$ (profil A) w odległości $500 \mathrm{~m}$, w profilu B - 1,92 kg/m/s w odległości $100 \mathrm{~m}$ oraz w profilu $\mathrm{C}-\mathrm{w}$ odległości $250 \mathrm{~m}$ od punktu początkowego stanowiącego skłon wydmy/klifu. Dominującą rolę w erozji odgrywa transport w zawiesinie, który stanowi niemal całość całkowitej erozji (St). Wielkość erodowanego osadu dennego jest niewielka i poza odcinkiem 100-450 m w profilu A (Mierzeja Helska) ma marginalne znaczenie (ryc. 7).

Założone wartości wzrostowe oparto na opracowaniu Warunki klimatyczne i oceanograficzne w Polsce i na Bałtyku Poludniowym - Spodziewane zmiany $i$ wytyczne do opracowania strategii adaptacyjnej $w$ gospodarce krajowej (Wibig, Jakusik, 2012). W scenariuszu A założono wzrost o $15 \%$ średnich wartości Hs i Tp, w B $-25 \%$, a w C $-50 \%$. We wszystkich analizowanych profilach występuję silna zależność między zadawanymi parametrami falowania 

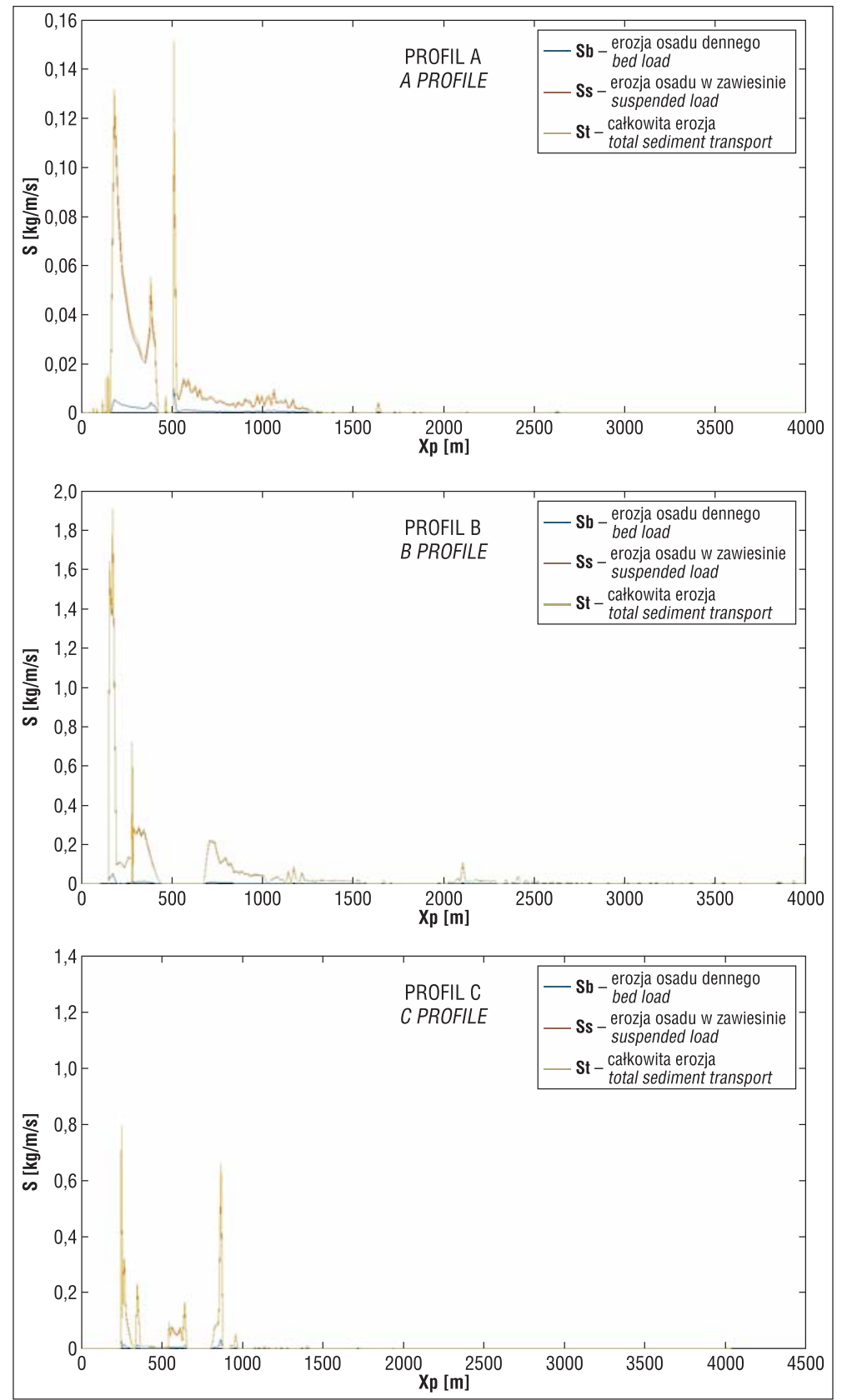

$\leftarrow$

Ryc. 7. Wielkość erozji $[\mathrm{kg} / \mathrm{m} / \mathrm{s}]$ w trzech analizowanych profilach dla średniej wysokości fali znacznej z okresu 1981-2020

Fig. 7. The amount of erosion $[\mathrm{kg} / \mathrm{m} / \mathrm{s}]$ in the three analyzed profiles for the mean height of the significant wave in the period 1981-2020

a odległością na profilu. Na profilu charakteryzującym Mierzeję Helską (ryc. 8A) silna erozja występuje głównie na odcinkach 50-75 m oraz w odległości $100 \mathrm{~m}$ od skłonu punktu początkowego transektu $(\mathrm{Xp}=0 \mathrm{~m})$ (skłon wydmy/klifu). Dla zmiennych scenariusza A i B wartości te sa zbliżone i wynoszą kolejno $0,6-1,0 \mathrm{~kg} / \mathrm{m} / \mathrm{s}$ na odcinku $50-75 \mathrm{~m}$ oraz $0,7-0,9 \mathrm{~kg} / \mathrm{m} / \mathrm{s} \mathrm{w}$ odległości $100 \mathrm{~m}$. Dla scenariusza C erozja całkowita wzrasta kolejno do $0,8-1,2 \mathrm{~kg} / \mathrm{m} / \mathrm{s}$ oraz $1,1 \mathrm{~kg} / \mathrm{m} / \mathrm{s}$. W profilu B (ryc. 8 B) we wszystkich analizowanych scenariuszach silna erozja występuje na odcinku $0-100 \mathrm{~m}$ i wynosi ona $0,5-2,25 \mathrm{~kg} / \mathrm{m} / \mathrm{s}$ dla scenariuszy A i B, a w scenariuszu C wartości te wzrosną do $2,77 \mathrm{~kg} / \mathrm{m} / \mathrm{s}$. Mierzeja Wiślana (ryc. 8C) w odróżnieniu do pozostałych analizowanych transektów nie charakteryzuje się wysokim stopniem erozji w żadnym ze scenariuszy, a największa jej wielkość występuje na odcinku 0-1000 m i nie przekracza $0,25 \mathrm{~kg} / \mathrm{m} / \mathrm{s}$.

\section{PODSUMOWANIE}

Prognozowanie wielkości erozji wybrzeża Zatoki Gdańskiej jest kluczowym narzędziem umożliwiającym planowanie potencjalnych miejsc dla inwestycji hydrotechnicznych czy wyznaczanie obszarów objętych refulacją oraz podczas podejmowania decyzji dotyczących sposobu ochrony brzegu i zastosowanych do tego różnych metod i technologii. Wraz z nasilającymi się zmianami klimatycznymi wzrasta ryzyko częstotliwości i wielkości niebezpiecznych zjawisk ekstremalnych, jakimi są sztormy
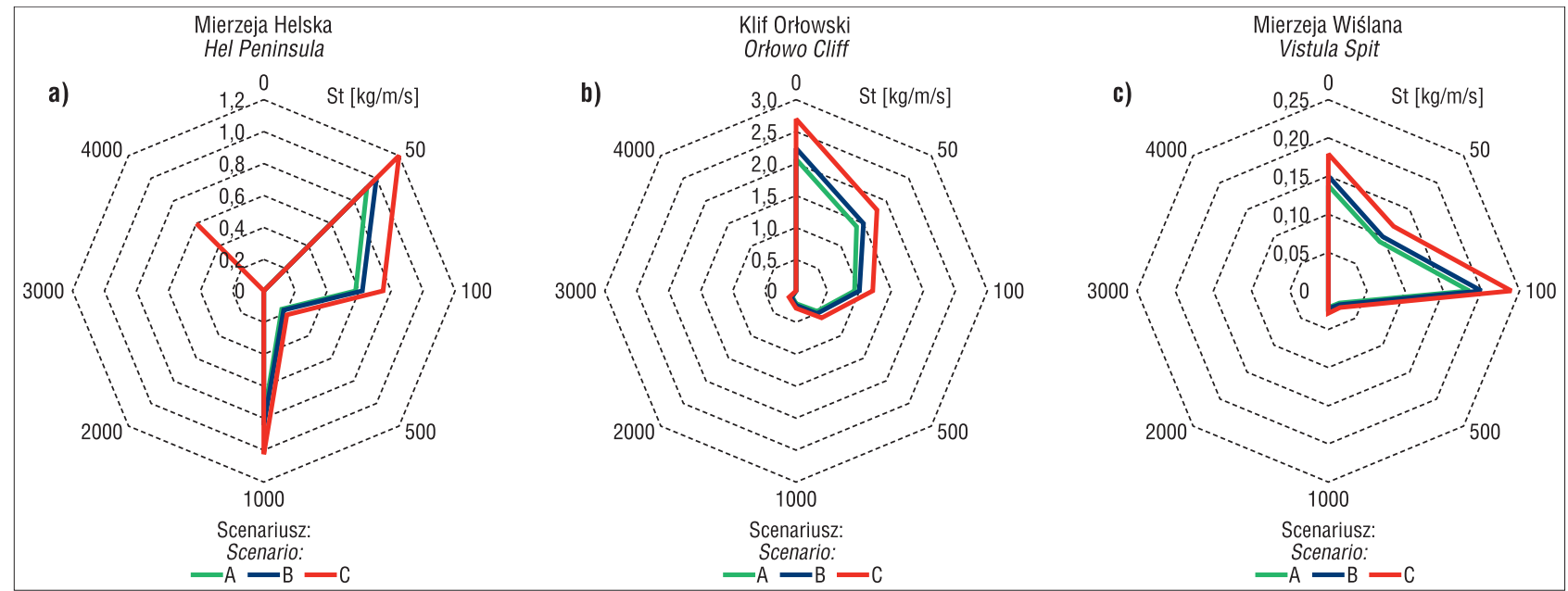

Ryc. 8. Prognozowana wielkość erozji (St) $[\mathrm{kg} / \mathrm{m} / \mathrm{s}]$ trzech scenariuszy (A-C) dla analizowanych transeptów [m]

Fig. 8. Projected amount of erosion $(\mathrm{St})[\mathrm{kg} / \mathrm{m} / \mathrm{s}]$ of the three scenarios $(\mathrm{A}-\mathrm{C})$ for the analyzed transects $[\mathrm{m}]$ 
i ich skutki. Obliczone wartości wielkości erodowanego brzegu (Sb, Ss, St) wskazują na zagrożenie sztormów przekraczających 2,5 m wysokości fali znacznej. Takie zjawiska nie zdarzają się często, jednak ich epizodyczne występowanie wyzwala ogromną ilość energii, która niesie za sobą wiele szkód. Poza zniszczeniami w infrastrukturze brzegowej, niszczone są również naturalne wały wydmowe, które stanowią ważny walor przyrodniczy. Założone scenariusze pokazują, że wzrost wysokości fali znacznej silnie koreluje z ilością wyerodowanego materiału osadowego. Dane reanalizy ERA-5, zawierające zgeneralizowane średnie wartości parametrów falowania, mogą być wykorzystywane zrówno jako tło do analiz bieżących, jak i do obliczeń $\mathrm{w}$ domenach o większej rozdzielczości przestrzennej. Przeprowadzona ocena oddziaływania falowania najwyższych fal sztormowych na strefe brzegową, w latach 2015-2020, może stanowić ważne narzędzie podczas oceny zmian środowiskowych, w szczególności w relacji klimat a zmiany.

Bardzo dziękuje recenzentowi Panu Piotrowi Szmytkiewiczowi za cenne i konstruktywne uwagi, które przyczyniły się do poprawy jakości artykułu.

\section{LITERATURA}

BONIECKA H. (red.) 2013 - Monitoring i badania dotyczące aktualnego stanu brzegu morskiego - ocena skuteczności systemów ochrony brzegu morskiego zrealizowanych $\mathrm{w}$ okresie obowiazywania wieloletniego „Programu ochrony brzegów morskich”. Instytut Morski w Gdańsku, nr 6973: 1-250. Gdańsk.

Copernicus Climate Change Service (C3S) 2017 - ERA5: Fifth generation of ECMWF atmospheric reanalyses of the global climate. Copernicus Climate Change Service Climate Data Store (CDS), date of access https://cds.climate.copernicus.eu/cdsapp\#!/home

DOBRACKI R., UŚCINOWICZ S. 2007 - Geozagrożenia polskiego brzegu Bałtyku. Prz. Geol., 55 (8): 639-640.
GRADZIŃSKI R., KOSTECKA A., RADOMSKI A., UNRUG R. 1986 Zarys sedymentologii. Wyd. Geol., Warszawa.

KAPIŃSKI J. OSTROWSKI R., PRUSZAK Z., SKAJA M., SZMYTKIEWICZ M., SZMYTKIEWICZ P. 2007 - Hydro- i morfodynamika strefy brzegowej w świetle badań terenowych (Lubiatowo'2006). Inż. Mor., 28 (3): 149-158.

PIKIES R., JUROWSKA Z. 1994 - Mapa geologiczna dna Bałtyku, ark. 12 Puck. Państw. Inst. Geol.

PRUSZAK Z., OSTROWSKI R. 2005 - Ustępujące wybrzeże, ginące plaże. Academia, Mag. PAN, 1 (1): 24-25.

PRUSZAK Z., SCHONHOFER J., SKAJA M., SZMYTKIEWICZ P. 2008 - Sezonowy wpływ falowania na zmienność linii brzegowej w przypadku wielorewowej strefy brzegowej. Inż. Mor., 29 (2): 72-77.

SZMYTKIEWICZ P., MORAWSKI M., RÓŻYŃSKI G. 2016 - Cross-Shore numerical model CSHORE for prediction of sand beach and dune erosion - region of Coastal Research Station at Lubiatowo. Inż. Mor., 37 (6): 333-339.

SZMYTKIEWICZ P., SCHONHOFER J., SZMYTKIEWICZ M. 2017 Zastosowanie modelu XBEACH do obliczania abrazji brzegu wydmowego na przykładzie obszaru położonego w rejonie Morskiego Laboratorium Brzegowego w Lubiatowie. Inż. Mor., 38 (2): 62-70

TUBIELEWICZ W., ONOSZKO J., SZOPKOWSKI Z., MOLSKI R. 1961 - Materiały do monografii polskiego brzegu morskiego. Wybrane zagadnienia dynamiki brzegu morskiego. PAN, Inst. Bud. Wod., 1: 1-60. WIBIG J., JAKUSIK E. (red.) 2012 - Warunki klimatyczne i oceanograficzne w Polsce i na Bałtyku południowym. Spodziewane zmiany i wytyczne do opracowania strategii adaptacyjnych w gospodarce krajowej. Instytut Meteorologii i Gospodarki Wodnej PIB Warszawa.

MASSIE W.W. 1986 - Coastal Engineering, vol. II - Harbor and beach problems, TU Delft, Department Hydraulic Engineering.

UŚCINOWICZ S., ZACHOWICZ J. 1993 - Mapa geologiczna dna Bałtyku, ark. 6 Gdańsk, ark. 7 Elblagg. Państw. Inst. Geol.

VAN RIJN, L.C. 2013 - Simple general formulae for sand transport in rivers, estuaries and coastal waters. Aqua Publications, Amsterdam.

VISSER P.J. 1984 - A mathematical model of uniform longshore currents and comparison with lab data, rep. nr. 82-1, fac. Civil Eng., Delft University.

ZAWADZKA-KAHLAU E. 1999 - Tendencje rozwojowe polskich brzegów Bałtyku południowego. Gdańskie Towarzystwo Naukowe, Gdańsk $1-147$.

Praca wpłynęła do redakcji 18.02.2021 r. Akceptowano do druku 1.10.2021 r. 